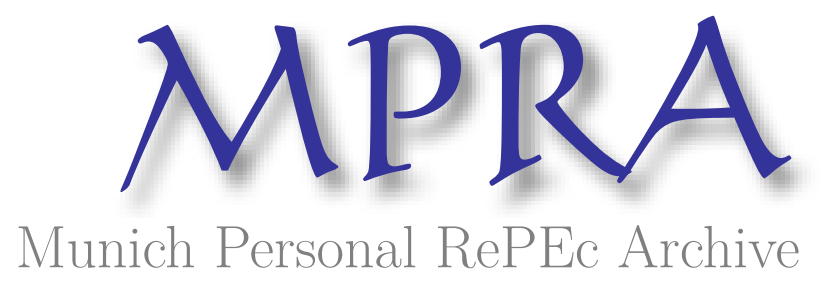

\title{
Market Access Strategies in the EU Banking Sector - Obstacles and Benefits towards an integrated European Retail Market
}

Beckmann, Rainer and Eppendorfer, Carsten and Neimke, Markus

Ruhr-Universität Bochum

2002

Online at https://mpra.ub.uni-muenchen.de/5273/

MPRA Paper No. 5273, posted 11 Oct 2007 UTC 


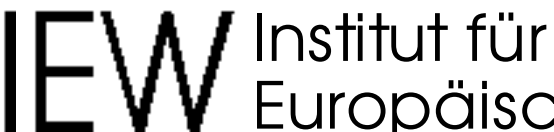

\section{Diskussionsbeiträge}

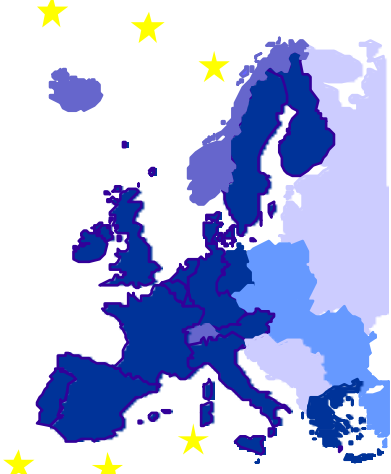

Carsten Eppendorfer, Rainer Beckmann and MarkusNeimke

Market Access Strategies in the EUBanking Sector: Obstacles and Benefits towards an integrated European Retail Market 
Anschrift derAutoren:

RainerBeckmann

Lehrstuhlfür Theoretische Volkswirtschaftslehre I

GC $3 / 147$

Tel.: 0049-(0)234/32-22776

email:rainer.beckmann@ ruhr-uni-bochum.de

Carsten Eppendorfer

LehrstuhlfürInternationaleWirtschaftsbeziehungen

GC $3 / 142$

Tel.: 0049-(0)234/32-22899

email: carsten.eppendorfer@ ruhr-uni-bochum.de

MarkusNeimke

LehrstuhlfürlnternationaleWirtschaftsbeziehungen

GC $3 / 143$

Tel.: 0049-(0)234/32-22898

email: markus.neimke@ ruhr-uni-bochum.de

Ruhr-Universität Bochum

FakultätfürWirtschaftswissenschaft

Universitätsstraße 150

D- 44780Bochum

Bochum

2002

Impressum:

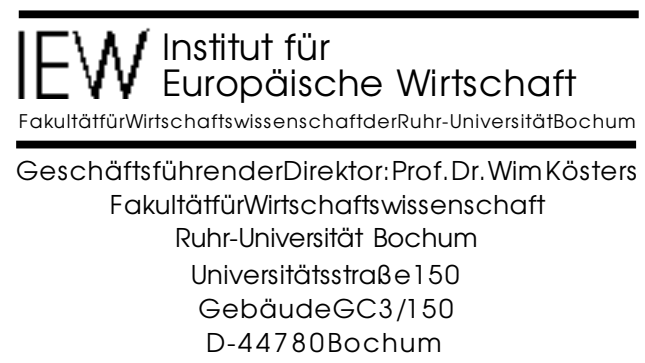

Telefon:(0234)/32-28888

Telefax:(0234)/32-14258

ISSN: $0945-6546$ 


\title{
Market Access Strategies in the EU Banking Sector Obstacles and Benefits towards an integrated European Retail Market*
}

\author{
Carsten Eppendorfer, Rainer Beckmann, Markus Neimke*** \\ Ruhr-Universität Bochum, Januar 2002
}

\begin{abstract}
The integration process in the European banking sector considerably differs with regard to product types. Deep integration can be observed in the money market as well as the market for wholesale products. In contrast to that, a strong segmentation of national markets still exists in the field of retail products. In this context, the paper analyses market access strategies of European banks. The analysis is based both on aggregate sectoral data and on four company case studies (BSCH, Nordea Group, BNP Paribas and $H S B C$ ). It is explored to which extent different market access strategies contribute to the integration of the European retail markets. A clear result is that mergers and acquisition as well as cooperations and strategic alliances form the most important market access strategies. Direct cross-border sales and the establishment of branches and subsidiaries are of minor importance. All strategies are complicated by considerable natural and politically induced barriers to market access. In particular, such politically induced barriers are different national supervision of banks, different tax legislation, as well as national accounting and take-over principles. Here, further harmonizations are suited to accelerate the integration of European retail markets and thus to increase consumer benefits by lower prices and a higher product variety for financial services.
\end{abstract}

JEL-Classification: G 21, G 28, G 34

Keywords: European integration, cross-border banking, mergers and acquisitions, regulations

*This paper is part of a study that was initiated and sponsored by the European Financial Services Round Table (EFR, Brussels). The EFR represents leading European banks and insurers and is devoted to the completion of a single market in financial services. The independent research team was headed by Friedrich Heinemann, Zentrum für Europäische Wirtschaftsforschung (ZEW, Mannheim) and Mathias Jopp, Institut für Europäische Politik (IEP, Berlin). For all results of the study see HEINEMANN and JOPP (2002). The other background papers are all downloadable in full text from www.zew.de/erfstudyresults/ or www.iepberlin.de/forschung/eu-market/.

**Acknowledgement: The authors gratefully acknowledge financial support from the European Financial Services Roundtable, Brussels. We also thank Prof. K.-O. Hammarkvist, Stockholm and Julien Carmona, Paris for valuable information and comments. 


\section{Introduction}

Over the last years, competition in the European banking sector has intensified considerably. The following factors have been decisive for the evolution of the European financial sector: the liberalization of the European financial sector, technological progress as well as an amplified diversification of savings and assets. The introduction of the Euro goes along with an accelerated integration of the market for financial services and leads to a further increase in competition and structural changes in the banking sector (DEUTSCHE BUNDESBANK, 1999; GALATI and TSATSARONIS, 2001). However, timeframe and depth of this structural change vary noticeably between the different sections of European banking. While the money market and the market for wholesale products (wholesale banking) already form a common European market, there still is an extensive segmentation of national markets for retail products (retail banking). Responsible for this low degree of integration in retail markets are a number of natural barriers, such as language or culture, as well as politically induced market access barriers such as regulations or taxation, which make cross-border trade in financial services more difficult (ECB, 1999a). Further deregulation and harmonization towards an integrated European retail market are suitable to increase customer benefits by fostering product diversification and lower prices.

Within the framework of this study, firstly, different market access strategies of the banking sector are systematized. Then it is analyzed, to which extent different strategies contribute to the integration of European retail markets. By examining the banks Banco Santander Central Hispano (Spain), Nordea Group (Sweden), BNP Paribas (France), as well as HSBC (England), market access strategies of four European top banks are illustrated in case studies. Secondly, motives, problems as well as consequences accompanied with these strategies are discussed. Thirdly, it is examined in detail which politically induced market access barriers currently complicate cross-border trade in financial services and which steps towards a further harmonization and integration are taken on EU level. Finally, consumer benefits of a future integration of European retail markets are discussed briefly.

\section{Importance of different market access strategies}

Basically, the variety of market access strategies in the banking sector can be summarized under four main headings. Direct cross-border sales mean trade of financial services without any physical presence of banks in target markets. This category comprises telephone banking, conventional mail marketing and, in particular, internet banking. The second strategy is the 
establishment of branches or subsidiaries in the target country. Mergers and acquisitions (M\&As) constitute the third strategy (ECB, 1999a). These are usually followed by considerable modifications in the organizational and legal structure of the respective companies. Finally, market access can be achieved by cooperations and strategic alliances. Here, it is decisive that there is only a minority stake.

\section{Direct cross-border sales}

Different market access strategies in the banking sector differ in the extent of their contribution to the integration of European retail markets. A low contribution is achieved by direct cross-border sales of financial services. Merely $2.8 \%$ of all credits to private non-banks occurred in 1999 were in the „cross-border“ category. Their growth rate of 23.5\%, however, appeared higher than the growth rate of domestic credits, which was 9.2\% (ECB, 2000a).

\section{Branches and subsidiaries}

The market share of foreign branches and subsidiaries (Table 1) - measured in relation to total bank assets - in 1997 was less than 10\%. Merely 3.4\% in European mean applied to branches. Higher market shares occurred only in Belgium (28.2\%), Ireland (45.4\%) as well as in Luxembourg (90.9\%). The small market share of foreign branches and subsidiaries confirms the assumption that banking operations in Europe concentrate on domestic markets to a considerable extent (ECB, 1999a and ECB, 1999b). Up to now, the „Freedom of establishment" for branches in Europe also had no essential impulse on further integration.

Table 1: Market share of foreign branches and subsidiaries from Europe in 1997 (as a percentage of total domestic assets)

\begin{tabular}{|c|c|c|c|c|c|c|c|c|c|c|c|c|c|c|c|}
\hline & & 恶 & 总 & 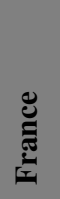 & 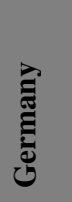 & ¿্巳 & 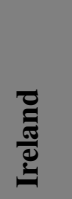 & $\stackrel{\frac{\lambda}{\pi}}{\underline{E}}$ & 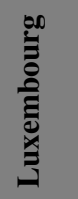 & 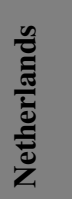 & 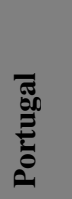 & $\begin{array}{l}\text { हूँ } \\
\text { है } \\
\text { है }\end{array}$ & 䂧 & 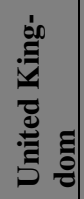 & ? \\
\hline $\begin{array}{l}\text { Market share of foreign } \\
\text { branches }\end{array}$ & 0.7 & 9.0 & 7.1 & \multirow{3}{*}{ 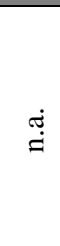 } & 0.9 & 11.1 & 17.7 & 3.6 & 19.4 & 2.3 & 2.5 & 1.3 & 4.8 & 22.5 & 3.4 \\
\hline $\begin{array}{l}\text { Market share of foreign } \\
\text { subsidiaries }\end{array}$ & 1.6 & 19.2 & -- & & 1.4 & 1.8 & 27.8 & 1.7 & 71.1 & 3.0 & 6.8 & -- & 3.4 & 1.0 & n.a. \\
\hline $\begin{array}{l}\text { Market share of total foreign } \\
\text { branches and subsidiaries }\end{array}$ & 2.3 & 28.2 & 7.1 & & 2.4 & 13.0 & 45.4 & 5.3 & 90.9 & 5.3 & 9.4 & 1.3 & 8.2 & 23.4 & n.a. \\
\hline
\end{tabular}

Source: ECB (1999a) and ECB(1999b) 


\section{Mergers and acquisitions}

Since the beginning of the 1990's, a substantial consolidation process within the banking sector can be observed. In particular, mergers and acquisitions led to a decreased number of banking institutions all over Europe. The amount of mergers and acquisitions in the European banking sector in 1997 was about 280, compared to 440 in 1999. In the same period, the aver age value of mergers and acquisitions tripled from 200 to 600 million Euro (ECB, 2000a and ECB, 2000b).

Up to now, however, the consolidation process concerned to a large extent the respective domestic market. In 1999, merely $19.5 \%$ of mergers and acquisitions within the European banking sector occurred cross-border, which means an increase in comparison to the 1997 figure of $16 \%(\mathrm{OECD}, 2001)$. Also taking into consideration cross-border mergers and acquisitions with non-European countries, the share is noticeably higher. This higher share is in particular attributed to the entry of European banks in Emerging Markets (ECB, 2000b). The trend of entering foreign markets by mergers and acquisitions to increase one's own market share still seems to intensify. The trend is accompanied by an increasing number of cooperations and strategic alliances. In comparison to other entry strategies, mergers and acquisitions seem to contribute most significantly to the integration of European retail markets in the future. The appendix shows the most important mergers and acquisitions within the European banking sector since the introduction of the Euro.

In addition to mergers and acquisitions within the banking sector, a number of cross-industry mergers and acquisitions involving banks can also be observed (conglomerates). In particular, large banks diversify their business fields with the objective of reaching broad market coverage in financial services (one-stop finance) (WILLMAN, 2000a). Not only capital investment companies (e.g. fund companies), but also insurance companies are the target objects of mergers and acquisitions in the banking sector. Up to now, however, mergers and acquisitions mainly were carried out within the banking sector. The share of domestic and cross-border conglomerates amounts to only $23 \%$ of all mergers and acquisitions with banking companies in the 1990's (OECD, 2001). An overview of the main types of M\&A is given in table 2.

\section{Prospect of future relative importance of strategies}

There are different assessments of the future importance of the different market access strategies with respect to the integration of the European retail market. However, there seems to be 
consensus with regard to the fundamental tendencies. For instance, direct cross-border sales of financial services - for example by internet - seems to be limited in spite of technological

Table 2: Main types of European M\&As in the banking industry

\begin{tabular}{|c|c|c|}
\hline & Within banking industry & Cross industry \\
\hline 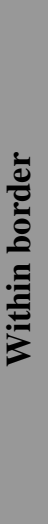 & $\begin{array}{l}\text { Domestic bank M\&As } \\
\text { M\&As involving credit institutions located in the same country. } \\
\text { Examples: } \\
\text { - } \quad \text { Banco Santander/Banco Central } \\
\text { Hispanoamericano (1999) } \\
\text { BNP/Paribas (1999) } \\
\text { The most dominant type of M\&As in the European banking } \\
\text { industry: } 60.7 \% \text { of all European banking M\&A transactions } \\
\text { between 1990 and 1999 took place within the domestic banking } \\
\text { industry (1990: 44\%, 1995: 45.8\%, 1999: } 61.4 \% \text { ) }\end{array}$ & $\begin{array}{l}\text { Domestic conglomeration } \\
\text { M\&As involving credit institutions and insurances and/or other } \\
\text { financial institutions all located in the same country. } \\
\text { Examples: } \\
\text { - Credit Suisse/Winterthur (1997) } \\
\text { Citicorp/Travelers Group (1998) } \\
\text { Less dominant than domestic M\&As within the banking indus- } \\
\text { try: 16.1\% of all banking M\&A transactions between } 1990 \text { and } \\
\text { 1999 were domestic cross industry transactions; after an in- } \\
\text { crease in the mid-nineties (1990: 16\%, 1995: 22.9\%, 1999: 12.5) } \\
\text { there are declining shares in the last years. }\end{array}$ \\
\hline 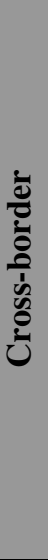 & $\begin{array}{l}\text { International bank M\&As } \\
\text { M\&As involving credit institutions located in different coun- } \\
\text { tries, one of which is an EU country. } \\
\text { Examples: } \\
\text { - Deutsche Bank/Bankers Trust (1998) } \\
\text { - HypoVereinsbank/Bank Austria (2000) } \\
\text { - Nordea Group (2000) } \\
\text { Less dominant than domestic bank M\&As but the most in- } \\
\text { creasing type of M\&As involving the banking industry: } 16.1 \% \\
\text { of all banking M\&A transactions between 1990 and 1999 were } \\
\text { cross-border bank M\&As (1990: } 30 \%, 1991: 10 \%, 1993: 10.8 \% \text {, } \\
\text { 1995:20.1\%, 1999: 19.5) }\end{array}$ & $\begin{array}{l}\text { International conglomeration } \\
\text { M\&As involving credit institutions located in an EU country } \\
\text { and insurances and/or other financial institutions located in } \\
\text { another EU or third country. } \\
\text { Examples: } \\
\text { • Deutsche Bank/Morgan Grenfell (1997) } \\
\text { • Dresdner Bank/Kleinwort Benson (1995) } \\
\text { Less dominant type of European M\&A transactions in recent } \\
\text { years and at present: 7.1\% of all transactions involving the } \\
\text { European banking industry between 1990 and 1999 were inter- } \\
\text { national cross industry transactions; after increasing shares in } \\
\text { the mid-nineties (1990: } 8 \%, 1995: 11.2 \% \text { ) there is a decline } \\
\text { during the last years (1997: } 9.6 \%, 1998: 8.5 \%, 1999: 6.5 \%) \text {. }\end{array}$ \\
\hline
\end{tabular}

Sources: Following ECB (2000b) and OECD (2001)

progress. In particular, different product definitions or missing proximity to customers are responsible here (HABERER, 1993 and SCHÜLER, 2002). The expansion of a new branch network abroad remains unattractive for financial reasons (fixed costs), because of existing overcapacities as well as due to new sale technologies (CROWDER, 1999; THE ECONOMIST, 1998; ACKERMANN, 1998 and HABERER, 1993). Furthermore, such "greenfield" investments are accompanied by high time exposures - not only concerning the setup of new brand names. Yields occur with a considerable time lag, which counteracts the interests of shareholders.

Presumably, mergers and acquisitions will represent the most important market access strategy in the future, too. However, due to disproportionate risks, a noticeable increase of crossborder mergers and acquisitions will not occur until consolidation on the domestic market has 
been completed (NAIRN, 2000). In this context, cooperations and alliances are taken as a strategy which is accompanied by lower risks. In particular, cooperations and alliances provide access to the distribution channels of foreign partners. While the trend to diversification in the field of large banks (one-stop finance) will be continuing, small and medium banks will increasingly specialize regionally and by the products offered and will unwind most parts of small customer business. For this reason, long-term integration of European retail markets seems to be limited - against the background of an extensive integration of money markets and wholesale markets (ECB, 1999a). Last but not least, the share of retail business by banks is regressive due to increasing disintermediation. An increasing importance of retail banking is only expected in the markets of Eastern Europe.

\section{Case Studies}

After the analysis of their macroeconomic importance we now examine different market access strategies of European banks within the framework of case studies of individual enterprises. For this purpose, market access strategies of Banco Santander Central Hispano $(B S C H)$, with their head offices in Spain, Nordea Group, headquartered in Sweden, BNP Paribas (France), as well as the HSBC, with head offices in England, are analyzed.

\section{Banco Santander Central Hispano}

Banco Santander Central Hispano (BSCH) is among the ten largest European banks, with a market capitalization of EUR 47 billion (2001) and 126,000 employees worldwide (Table 3). The market access strategies pursued by $\mathrm{BSCH}$ comprise direct cross-border sales, the foundation of branches, as well as mergers and acquisitions. For the purpose of direct sales of financial services, the group set up the European Internet Bank Patagon as well as the phone bank Santander Direkt. The worldwide branch network currently contains 10,800 branches in 42 countries. Mergers and acquisitions can be classified as the most important market access strategy of the BSCH within Europe. A cross-border expansion took place here particularly in the Portuguese, the German as well as in the Italian market. Mergers and acquisitions were complemented through the exchange of know-how with various European partners in the form of cooperations and strategic alliances. Offering a wide range of products through various channels of distribution can be considered as a goal of BSCH's market access strategy. The internet will take an important position in the future sales of financial services (BsCH, 2001). 
Table 3: Market Access Strategy of Banco Santander Central Hispano (BSCH)

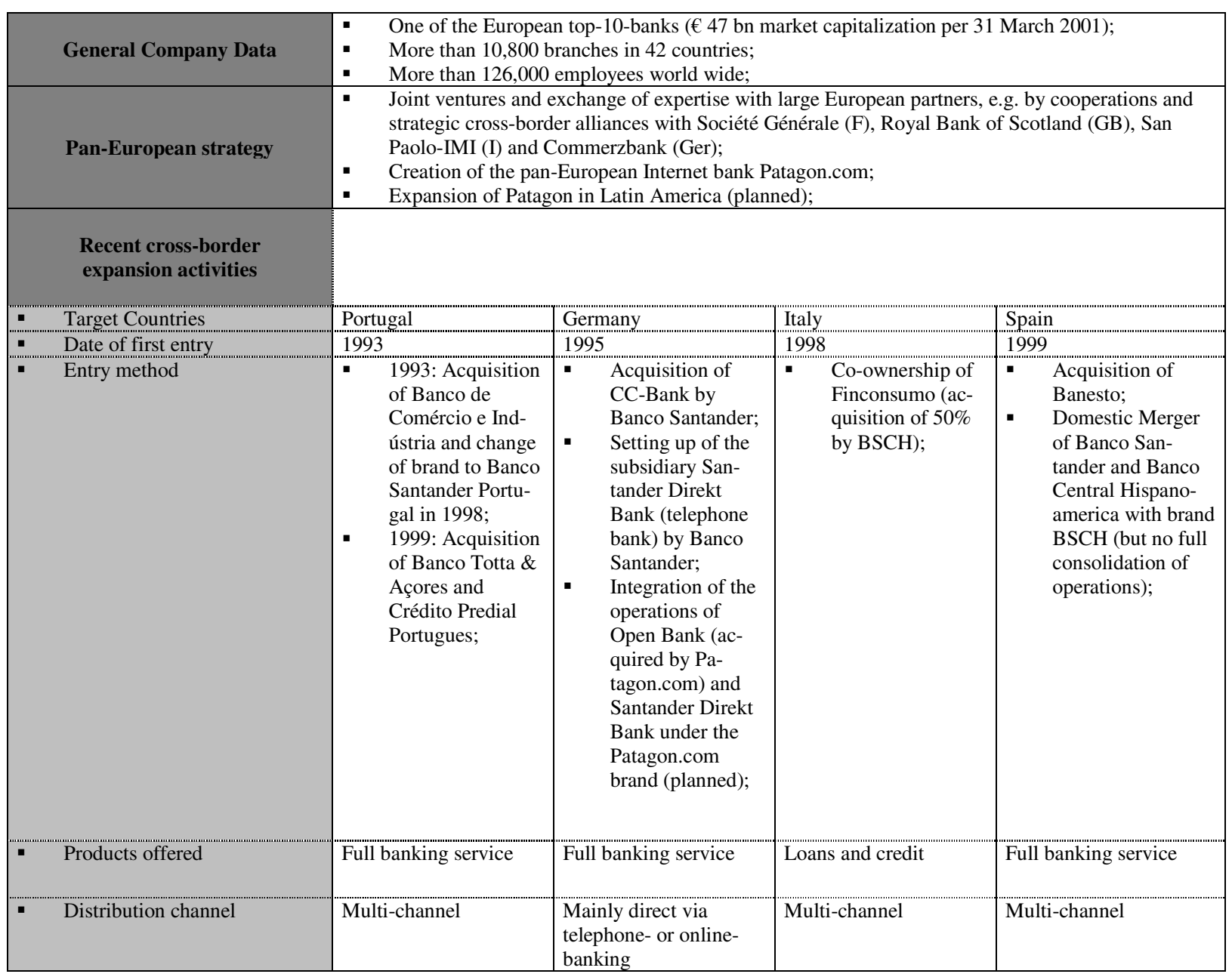

Source: Following DATAMONITOR (2000) and BSCH (2001)

\section{Nordea Group}

The merger of Merita (Fin) and Nordbanken (Swe) in 1998 was the first cross-border merger of two European top banks of the same size (Table 4). The consortium expanded in 2000 by the merger of MeritaNordbanken and Unidanmark (DK). After an acquisition of Christiania Bank og Kreditkasse (Nor) was rejected first by the Norwegian government, in 2000 MeritaNordbanken, Unidanmark and Christiania Bank og Kreditkasse finally formed Nordea Group, which represents the largest bank consortium in Northern Europe, with a market capitalization of approx. EUR 20 billion (2001), 1,481 branches and 37,630 employees. The main motives to form Nordea were different kinds of synergies (e.g. economies of scale ond scope) as well as an increased market share in the nordic market, including also Estonia, Latvia, Lithuania and Poland. Nordea Group pursues a multi-channel distribution strategy that contains one of the most successful phone (e.g. WAP banking in cooperation with Nokia) and internet services of the world, offering almost complete services of the Nordea Group. The cross industry 
merger of Unidanmark and the insurer Tryg-Baltica (DK) forced the selling of insurance produkts (household and general insurance) too (one-stop finance). Using a multi-channel distribution strategy, e.g. the common internet bank (Solo Internet Bank), existing barriers to market access ought to be bypassed. In the context of politically induced barriers to market access, especially different national supervision institutions, different consumer protection rules (e.g. different deposit guaranty systems or cross-border management of bank secrets) and different national tax legislations (e.g. Danmark) are mentioned by Nordea Group. Last but not least, Nordea Group could strongly contribute to the integration of financial services market in Northern Europe due to the smaller cultural and social differences between the northern in comparison to the southern countries in Europe. However, after the consolidation process is completed and all synergies are realized, further expansion, following real trading patterns with direction south (e.g. Germany, Netherlands) is the natural way to go (NORDEA, 2001).

\section{Table 4: Market Access Strategy of Nordea Group}

\begin{tabular}{|c|c|c|c|c|c|}
\hline \multicolumn{2}{|c|}{ General Company Data } & \multicolumn{4}{|c|}{$\begin{array}{l}\text { - MeritaNordbanken, Unidanmark and Christania Bank form the nordic fir } \\
\text { (almost } € 20 \text { bn market capitalisation per August 2001); } \\
\text { - } \quad \text { Nordea Group has a strong distribution network throughout the Nordic a } \\
\text { which comprises } 1,481 \text { branch offices or Internet-service centres with } 37 \\
\text { - Nordea is present in } 22 \text { countries including } 14 \text { countries outside the Norc }\end{array}$} \\
\hline & Pan-European strategy & \multicolumn{4}{|c|}{$\begin{array}{l}\text { - } \quad \text { One-bank-shopping-concept": to provide a single point of entry for cust } \\
\text { get access to the entire supply of services of all integrated banks; single b } \\
\text { banks from December 2001; } \\
\text { - Branches network in the Nordic region, representative offices and cooper } \\
\text { the most important European cities and countries; } \\
\text { - Integrated Internet-banking: Solo as a full-service Internet bank; }\end{array}$} \\
\hline \multicolumn{6}{|c|}{$\begin{array}{c}\text { Recent } \\
\text { expansion activities }\end{array}$} \\
\hline - & Target Countries & Finland and Sweden & Denmark & Norway & Sweden \\
\hline - & Date of first entry & 1998 & 2000 & 2000 & 2001 \\
\hline \multirow{2}{*}{\multicolumn{2}{|c|}{ Entry method }} & $\begin{array}{l}\text { Merger between } \\
\text { Merita (Fin) and } \\
\text { Nordbanken (S) into } \\
\text { MeritaNordbanken } \\
\text { with Nordic Baltic } \\
\text { Holding as the } \\
\text { bank's holding } \\
\text { company; }\end{array}$ & $\begin{array}{l}\text { Acquisition of } \\
\text { Unidanmark by } \\
\text { MeritaNordbanken; }\end{array}$ & $\begin{array}{l}\text { Acquisition of } \\
\text { Christiania } \\
\text { Bank og } \\
\text { Kredtkasse to } \\
\text { form Nordea } \\
\text { Group; }\end{array}$ & $\begin{array}{l}\text { Acquisition of } \\
\text { Postgirot (Swe) } \\
\text { by Nordea; }\end{array}$ \\
\hline & & \multicolumn{4}{|c|}{$\begin{array}{l}\text { 2000: Integration of Christiania Bank og Kreditkasse (K-Bank) (Nor), Merita Bank (Fin), } \\
\text { Nordbanken (Swe) and Unidanmark (DK) into Nordea Group; }\end{array}$} \\
\hline & Products offered & \multicolumn{4}{|c|}{$\begin{array}{l}\text { Allfinance (incl. lifeinsurance products in all nordic countries and non lifeinsurance products in } \\
\text { Norway, Denmark and Finland) } \\
\text { - Cross-selling potential due to the integration into Nordea }\end{array}$} \\
\hline & Distribution channel & \multicolumn{4}{|c|}{$\begin{array}{c}\text { Multi-channel } \\
\text { (branches, telephone, internet) }\end{array}$} \\
\hline
\end{tabular}

Source: Following DATAMONITOR (2000) and NORDEA (2001) 


\section{BNP Paribas}

BNP Paribas $(\mathrm{F})$ is among the ten largest European banks, with a market capitalization of EUR 41.9 billion (2001) and 80,000 employees worldwide (Table 5). BNP Paribas was formed by a domestic merger of BNP (F) and Paribas (F) in 2000. In the 1980s, Paribas entered the Spanish market by establishing a new branch net. These branches were sold in 2000 due to high fixed costs against the backround of a relativly low market share. For the same reason Paribas sold its branches in Belgium and the Netherlands in 1997. Currently, BNP Paribas only in France operates through a branch net of its own. Cross-border distribution predominantly is conducted through branches of European partners. For instance, market access to Germany was obtained by a joint venture of BNP Paribas and Dresdner Bank in 2000.

\section{Table 5: Market Access Strategy of BNP Paribas}

\begin{tabular}{|c|c|c|c|c|}
\hline General Company Data & \multirow{2}{*}{\multicolumn{4}{|c|}{$\begin{array}{l}\text { - } \quad \text { One of the European top-ten-banks (market capitalisation at } 31 \text { Dec } 2000: € 41.9 \text { bn; } \\
\text { - } \quad \text { Operations in } 87 \text { countries in Europe, Asia and United States; } \\
\text { - } \quad 80,000 \text { employees, including } 61,000 \text { in Europe, including 49,000 in France; } \\
\text { - } \quad \text { Network of } 2,200 \text { branches in France, } 13.1 \text { million retail customers in the EU; } \\
\text { - } \quad \text { Set-up of Multichannel Bank; } \\
\text { - } \quad \text { Cross-selling between the various business units and with other divisions of the Group; }\end{array}$}} \\
\hline Pan-European strategy & & & & \\
\hline \multicolumn{5}{|l|}{$\begin{array}{c}\text { Recent } \\
\text { expansion activities }\end{array}$} \\
\hline Target Countries & France & "Germany & 'Spain & Pan-European \\
\hline Date of first entry & 2000 & 2000 & 1980 's & $1990 ` \mathrm{~s}$ \\
\hline - $\quad$ Entry method & $\begin{array}{l}\text { Merger between } \\
\text { BNP and Paribas } \\
\text { to create BNP } \\
\text { Paribas; } \\
1998 \text { merger } \\
\text { between Com- } \\
\text { pagnie Financière } \\
\text { de Paribas, } \\
\text { Banque Paribas } \\
\text { and Compagnie } \\
\text { Bancaire to form } \\
\text { Paribas; } \\
\text { 1993 Privatisation } \\
\text { of BNP }\end{array}$ & $\begin{array}{l}\text { Joint venture } \\
\text { between BNP } \\
\text { Paribas and } \\
\text { Dresdner Bank }\end{array}$ & $\begin{array}{l}\text { Establishing of a } \\
\text { branch net (sold } \\
\text { in 2000) }\end{array}$ & $\begin{array}{l}\text { Different market access } \\
\text { strategies (e.g. "Cardif- } \\
\text { model", "Cetelem- } \\
\text { model") }\end{array}$ \\
\hline - $\quad$ Products offered & Full banking service & Consumer finance & $\begin{array}{l}\text { Private Banking (only } \\
\text { wealthy customers) }\end{array}$ & Full banking service \\
\hline - Distribution channel & "Multi-channel & Multi-channel & Traditional & Multi-channel \\
\hline
\end{tabular}

Source: BNP PARIBAS (2001)

Furthermore BNP Paribas distributes retail products via the subsidiaries Cardif (bank insurer) and Cetelem (consumer bank). Cardif predominantly sells through branches (direct marketing or telemarketing) of pan-European partners (banks, finance companies, commercial firms and insurers). In France Cardif cooperates with Crédit du Nord, Banque Directe, Banque Hervet as well as Cartol. Cetelem distributes a complete range of financial products through branches of foreign partners (cooperations and alliances with retail banks and financial institutions) 
such as Savings Bank of Florence (Ita), Caixa Galicia (Spa) Dresdner Bank (Ger) and others. Via partnerships with Ikea, Carrefour or Conforama Cetelem also conducts point-of-sale finance. A further pan-European strategy comprises the constitution of product specialists (e.g. for online brokerage or mortgages), who cooperate with partners abroad. These different kinds of cooperations and alliances are suited to bypass barriers to market access. Here in particular different national tax legislation or accounting standards, as well as different consumer protection regulations are noted by BNP Paribas (BNP PARIBAS, 2001).

\section{$H S B C$}

With 23 million customers and approx. 6,500 offices in 78 countries, $H S B C$ is one of the largest providers of financial services in the world (Table 6).

Table 6: Market Access Strategy of HSBC

\begin{tabular}{|c|c|c|c|c|c|}
\hline General Company Data & \multirow{2}{*}{\multicolumn{5}{|c|}{$\begin{array}{l}\text { - } \quad \text { One of the European top-10-banks (more than } € 125 \text { bn market capitalisation per August 2001); } \\
\text { - } 6,500 \text { offices in } 78 \text { countries; } \\
\text { - } \quad \text { Global online banking and investment services: creation of the Merrill Lynch-HSBC online bank; } \\
\text { - } \quad \text { Focus on expansion by organic growth complemented with strategic acquisitions; }\end{array}$}} \\
\hline Pan-European strategy & & & & & \\
\hline \multicolumn{6}{|l|}{$\begin{array}{c}\text { Recent } \\
\text { expansion activities }\end{array}$} \\
\hline - Target Countries & Luxembourg & Spain & United Kingdom & France & Greece \\
\hline Date of first entry & 1977 & 1982 & 1992 & 1881 & 2001 \\
\hline - $\quad$ Entry method & $\begin{array}{l}\text { In- } \\
\text { dependent } \\
\text { start-up } \\
\text { (HSBC } \\
\text { Luxem- } \\
\text { bourg); }\end{array}$ & $\begin{array}{l}\text { In- } \\
\text { dependent } \\
\text { start-up } \\
\text { (HSBC } \\
\text { Spain); }\end{array}$ & $\begin{array}{l}\text { Midland Bank } \\
\text { becomes wholy } \\
\text { owned member } \\
\text { of the HSBC } \\
\text { Group; Midland } \\
\text { bank was re- } \\
\text { named HSBC } \\
\text { bank in 1999; } \\
\text { 2000: partner- } \\
\text { ship with } \\
\text { Merrill Lynch } \\
\text { to create a } \\
\text { global online } \\
\text { banking and in- } \\
\text { vestment serv- } \\
\text { ices company } \\
\text { (Merrill Lynch- } \\
\text { HSCB); }\end{array}$ & $\begin{array}{l}\text { 2000: Acquisi- } \\
\text { tion of Crédit } \\
\text { Commercial de } \\
\text { France }(\mathrm{CCF})\end{array}$ & $\begin{array}{l}\text { Acquisition } \\
\text { of the Bar- } \\
\text { clays } \\
\text { branches; }\end{array}$ \\
\hline - Products offered & \multicolumn{2}{|c|}{$\begin{array}{l}\text { Private banking with focus on } \\
\text { wealthy customers }\end{array}$} & Full banking service & $\begin{array}{l}\text { Private banking with } \\
\text { a more comprehen- } \\
\text { sive product range } \\
\text { than in other coun- } \\
\text { tries }\end{array}$ & Private banking \\
\hline - Distribution channel & \multicolumn{2}{|c|}{ Traditional } & \multicolumn{2}{|c|}{ Multi-channel } & Traditional \\
\hline
\end{tabular}

Source: Following DATAMONITOR (2000) and HSBC (2001)

HSBC started as a colonial bank in Hong Kong from where the company expanded to Asia and the rest of the world. On the European market, HSBC was represented noticeably only in England for a long time. Market shares in Luxembourg, Spain and France were low. With the 
take-over of $C C F$ in 2000, the enterprise gave up its strategy of organic growth and acquired large market shares in France. While in England HSBC concentrates on mass market, the take-over of CCF targets personal asset management of customers in the middle and upper wealth bracket. The joint venture of HSBC and Merrill Lynch marks the first connection of this kind worldwide. The offer of Merrill Lynch-HSBC contains broker as well as retail services, whereby all services are offered exclusively over the internet (HsBC, 2001).

\section{What can we learn from these case studies?}

From the viewpoint of individual enterprises, the cases of Banco Santander Central Hispano, Nordea Group, BNP Paribas as well as HSCB clarify which important role mergers and acquisitions play within the integration of European retail markets. The case studies confirm the macroeconomic observation on the different importance of different strategies to market access. All of the examined banks pursue multi-channel distribution strategies. However, important cross-border market shares are predominantly acquired by mergers and acquisitions (e.g. acquisition of $C C F$ by $H S B C$, merger of Merita and Nordbanken) as well as cooperations and alliances (e.g. BNP Paribas). In addition, particulary the foundation of telephone- and internet banks (e.g. Patagon, Santander Direkt Bank, Solo Internet Bank or Merrill Lynch$H S B C$ ) are of increasing importance. A considerable technical progress with regard to communication technologies accelerates this development. The foundation of branches or subsidiaries is - for the reasons mentioned above (fixed costs, problems in establishing new brand names, yields with significant time lags) - of no considerable future importance. The example of BNP Paribas clarifies, that there is even a trend to decrease the number of branches.

As mergers and acquisitions is the most important strategy the motives and risks accompanied by different forms of mergers and acquisitions are summarized in table 7. Economies of scale and economies of scope are regarded as the most important motives for the execution of mergers and acquisitions. In addition to these cost-sided arguments, higher market shares as well as product- and risk diversity are particularly important (NAIRN, 2000). 
Table 7: Motives and risks with four types of Mergers \& Acquisitions (M\&As)

\begin{tabular}{|c|c|c|}
\hline & Within banking industry & Cross industry \\
\hline 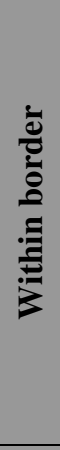 & $\begin{array}{l}\text { Domestic bank M\&As } \\
\text { Main motives: } \\
\text { - } \quad \text { Cost benefits from economies of scale, e.g. } \\
\text { by reduction of surplus staff and overlapping branches or } \\
\text { mutual use of administrative functions; } \\
\text { - Increasing market share; } \\
\text { Main risks: } \\
\text { - } \quad \text { Pricing of the strategic risks; } \\
\text { Operational risks after the transaction, mainly related to } \\
\text { the integration of personnel, information and risk man- } \\
\text { agement, customer and account systems etc. } \\
\end{array}$ & $\begin{array}{l}\text { Domestic conglomeration } \\
\text { Main motives: } \\
-\quad \text { Cost benefits from economies of scope through cross-selling; } \\
-\quad \text { Revenue enhancement due to product diversification; } \\
\text { Risk diversification; } \\
\text { Main risks: } \\
-\quad \text { Increased ex ante risks because of different business area; } \\
\text { - Reputation risks (failure of one company may lead to declin- } \\
\text { ing reputation of the whole conglomerate); } \\
\text { Increased integration difficulties due to different fiscal and } \\
\text { accounting treatment etc. }\end{array}$ \\
\hline 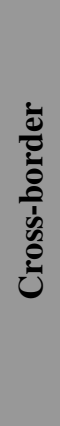 & 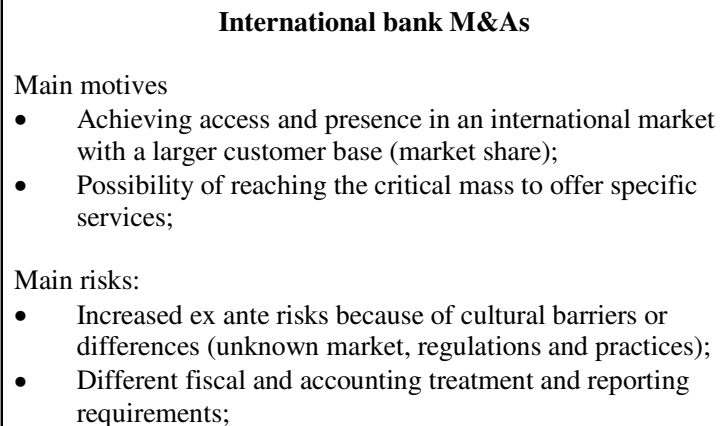 & $\begin{array}{l}\text { International conglomeration } \\
\text { Main motives: } \\
\qquad \quad \text { Cost benefits from economies of scope through cross-selling; } \\
-\quad \text { Access and presence in international financial markets; } \\
\text { - } \quad \text { International product diversification; } \\
\text { Main risks: } \\
-\quad \text { Increased ex ante risks due to a different business area; } \\
-\quad \text { Different fiscal and accounting treatment and reporting re- } \\
\quad \quad \text { quirements; } \\
\text { - }\end{array}$ \\
\hline
\end{tabular}

Source: Following ECB (2000b)

Risks result in particular from the integration of different enterprise cultures and business fields. Furthermore general factors affecting all companies include risks and represent barriers to market entry. For instance, "natural barriers" like different cultures or different consumer preferences are of high relevance, as are "politically induced barriers" like different national tax-legislation or different regulations (BUCH, 2001). Due to low natural barriers Nordea Group became the largest bank consortium in Northern Europe, and likewise Banco Santander Central Hispano strongly expanded only in Southern Europe (NAIRN, 2000). Because of different politically induced barriers to market access, all of the examined banks follow a multi-channel strategy in cross-border trade (e.g. BNP Paribas). However, politically induced barriers of market access are often responsible for the failure of market access (ECB, 2000a). 
Table 8: Withdrawn M\&As in the banking industry

\begin{tabular}{|c|l|l|l|}
\hline Year & \multicolumn{2}{|c|}{ Involved banks } & Reasons for failure \\
\hline 1999 & Bank of Ireland (Irl) & $\begin{array}{l}\text { Alliance and Leicester } \\
\text { (UK) }\end{array}$ & Disagreements of the involved parties; \\
\hline 1999 & BNP (Fra) & Société Générale (Fra) & Rejection by french banking regulators \\
\hline 2000 & Dresdner Bank (Ger) & Deutsche Bank (Ger) & $\begin{array}{l}\text { The Dresdner Bank broke off the merger talks due to } \\
\text { Deutsche Bank's insistence that Dresdner sell off its } \\
\text { investment bank Kleinwort Benson in whole or in } \\
\text { pieces; }\end{array}$ \\
\hline 2001 & Unicredito (Ita) & $\begin{array}{l}\text { Commerzbank (Ger) } \\
\text { Disagreement on valuation and price of the transaction; }\end{array}$ \\
\hline 2001 & $\begin{array}{l}\text { SEB (Swe) } \\
\text { (created out of merger of Enba's (parent company of } \\
\text { Irish Internet-only bank First-e) (IRL) and BBVA's } \\
\text { (UK) internet subsidiaries) }\end{array}$ & $\begin{array}{l}\text { Rejection by the European Commission due to objec- } \\
\text { tions with regard to antitrust law; }\end{array}$ \\
& $\begin{array}{l}\text { Collapse due to some disagreements with respect to } \\
\text { ownership of the technology, regulatory uncertainty, the } \\
\text { sharp fall in high-tech stocks and a reassessment of the } \\
\text { short-term potential of Internet banks (according to } \\
\text { Business \&Finance online); }\end{array}$ \\
\hline
\end{tabular}

Source: FinANCIAL Times DEuTSCHLAND (2001a), FinANCIAL TimES DEUTSCHLAND (2001b),

BUSINESS\&FINANCE (2001) and BBC NEWS (2001)

Table 8 shows cases of withdrawn mergers and acquisitions. As can be seen in addition to disagreements of the involved parties, rejection by governments or regulatory institutions as well as regulatory uncertainties often prevent successful market access.

Beyond the case studies, empirical evidence with regard to different barriers to market access, stems from a QUESTIONING OF LEADING PAN-EUROPEAN BANKING GROUPS conducted in 2001 (Table 9). Natural obstacles like language or consumer preferences noticeably hinder market access. In contrast market infrastructure or market attractivness seem to be of minor relevance. Within the politically induced barriers especially different tax legislation seem to be of particular importance. Both, tax legislation and regulations specific to each country represent - with different levels of importance - the most important obstacles for all of the abovementioned market access strategies of banks and thus to the integration of European retail markets. Furthermore, politically induced barriers - unlike natural barriers - can be removed by political decisions to increase the potential of future integration and consumer benefits. Therefore, politically induced barriers are now discussed in more detail. 
Table 9: Relevance of different barriers to market access in regard to retail bank products

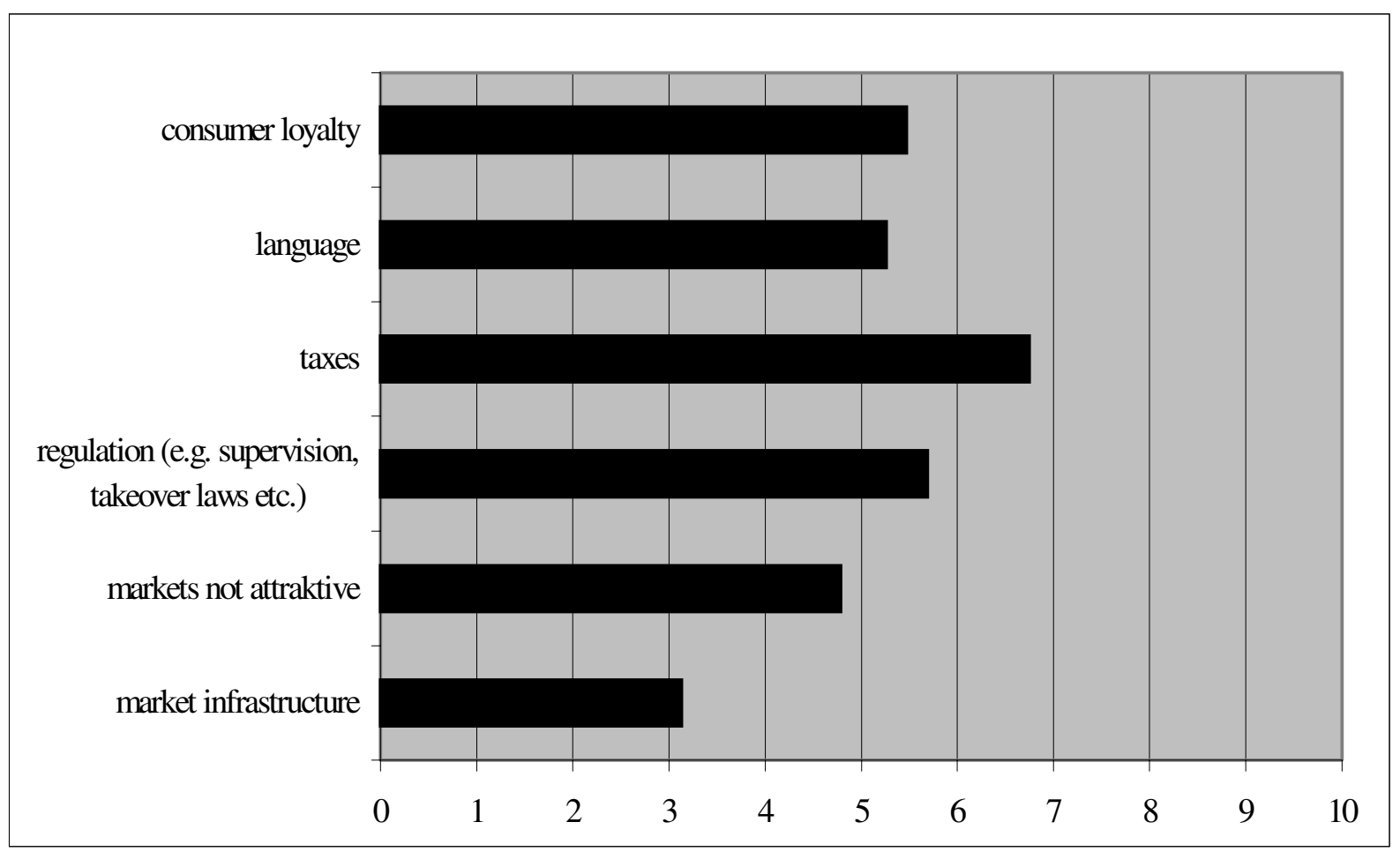

The importance of different barriers is measured by using a scale from 10 (highly relevant) to 1 (no relevance at all). Source: QUESTIONING OF LEADING PAN-EUROPEAN BANKING GROUPS (2001).

\section{Politically induced barriers of cross-border bank activities}

Legal regulation with the purpose of creating a common European market for financial services of the banking sector are based on a line of decisions and directives (e.g. Single Market Program, 1992) of the last thirty years (Table 10). In addition to the „Freedom of establishment", arrangements relating to bank supervision are of considerable importance with regard to market access decisions of banks. Bank supervision is based on two elements: firstly, on national responsibility (principles of supervision by the home country and the mutual recognition of admission), and secondly, on the cross-border cooperation of national supervisory institutions. Furthermore, a minimum harmonization of regulations should be guaranteed (ECB, 2000a). 
Table 10: EU Financial Services Directives (Single Market Program)

\begin{tabular}{|c|c|c|c|c|}
\hline \multirow{2}{*}{$\begin{array}{l}\text { Freedom of establish- } \\
\text { ment }\end{array}$} & $1970 \ldots$ & \multirow[t]{2}{*}{$1980 \ldots$} & \multirow[t]{2}{*}{$1990 \ldots$} & $2000 \ldots$ \\
\hline & & & & \\
\hline First Banking Directive & & & & \\
\hline Basel Capital Accord & & & & \\
\hline $\begin{array}{l}\text { Second Banking Direc- } \\
\text { tive }\end{array}$ & & & & \\
\hline $\begin{array}{l}\text { Cross-border credit } \\
\text { transfers }\end{array}$ & & & & \\
\hline $\begin{array}{l}\text { Third stage of EMU } \\
\text { (mutual currency) }\end{array}$ & & & & \\
\hline New Basel Accord & & & & \\
\hline
\end{tabular}

Source: EU (2001a) and EU (2001b)
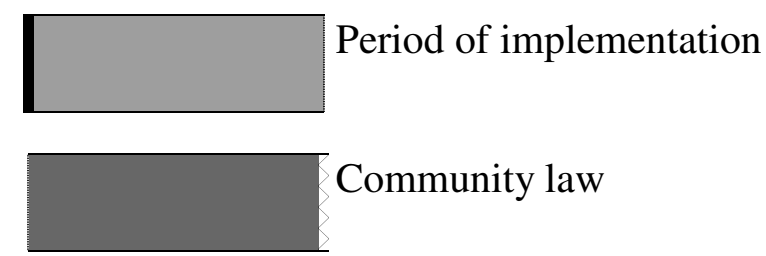

Since 1999, the European Union is improving the general conditions for further integration of the market for financial services within the framework of the "Financial Services Action Plan (FSAP)". In addition to the retail and wholesale market, measures also concern the position of the European financial market in relation to non-European financial markets. An overview is given in table 11 .

From the perspective of European banks, however, there is still a line of obstacles which hinders cross-border trade in financial services (QUESTIONING OF LEADING PAN-EUROPEAN BANKING GROUPS, 2001 (Table 9) and SCHRÖDER, 2001). For instance, the principle of mutual recognition often is not applied in practice. Although the supervision by the home country is valid for foreign branches, solvency control, for instance, is under the supervision of the host country. This makes expansion of a branch network abroad complicated. The strategies of Banco Santander Central Hispano, Nordea Group, HSBC and especially of BNP Paribas confirm the problems of creating a branch net abroad. 
Table 11: Objectives of the Financial Services Action Plan (FSAP)

\begin{tabular}{|c|c|}
\hline Strategic objective & Actions in order to achieve the strategic objective are needed to ... \\
\hline A single EU wholesale market & $\begin{array}{l}\text { - enable corporate issuers to raise capital on competitive terms on an EU-wide } \\
\text { basis; } \\
\text { provide investors and intermediaries with access to all markets from a single } \\
\text { point-of-entry; } \\
\text { - allow investment service providers to offer their services cross-border without } \\
\text { encountering unnecessary obstacles or administrative or legal barriers; } \\
\text { to establish a sound and well integrated prudential framework within which } \\
\text { asset managers can put funds at their disposal to their most productive use; } \\
\text { create a legal certainty so that securities trades and settlement are safe from } \\
\text { unnecessary counterparty risk; }\end{array}$ \\
\hline $\begin{array}{l}\text { Open and secure retail mar- } \\
\text { kets }\end{array}$ & $\begin{array}{l}\text { - equip consumers with the necessary information and clear rights to permit their } \\
\text { full and active participation in the single financial market; } \\
\text { identify and counteract unjustified insistence on non-harmonised consumer- } \\
\text { business rules as an obstacle to cross-border provision of services; } \\
\text { create legal conditions in which new distribution channels and distance tech- } \\
\text { nologies can be put to work on a pan-European scale; } \\
\text { - encourage the emergence of cost-effective and secure payment systems which } \\
\text { enable citizens to effect small-value cross-border payments without incurring } \\
\text { exorbitant charges; }\end{array}$ \\
\hline $\begin{array}{l}\text { State-of-art prudential rules } \\
\text { and supervision }\end{array}$ & $\begin{array}{l}\text { - eliminate any gaps in EU prudential framework, arising from new forms of } \\
\text { financial business or globalisation; } \\
\text { - } \\
\text { set rigorous and appropriate standards so that the EU banking sector can suc- } \\
\text { enable the EU to assume a key role in setting high global standards for regula- } \\
\text { tion and supervision, including financial conglomerates; }\end{array}$ \\
\hline $\begin{array}{l}\text { Wider conditions for an opti- } \\
\text { mal single financial market }\end{array}$ & $\begin{array}{l}\text { - eliminate disparities in tax treatment } \\
\text { - create an efficient and transparent legal system for corporate governance }\end{array}$ \\
\hline
\end{tabular}

Source: Following EUROPÄISCHE KOMMISSION (1999) and EUROPEAN COMMISSION (2001)

Furthermore - as stated e.g. by BNP Paribas - consumer protection regulations differ within European countries. For cross-border sales of financial services, this calls for compliance to additional requirements in the respective countries. Additional information costs arise and thus hinder cross-border sales - for example via internet - especially of small and mediumsized enterprises. Such obstacles are often used to protect domestic markets. In contrast, large enterprises - like the cases of Nordea Group (Solo Internet Bank) as well as HSBC (Merrill Lynch-HSBC) show - use the internet to bypass certain barriers to market access. Different national supervision practice (different competences of the respective national institution as well as different reporting requirements for companies) set up such barriers - in particular with regard to cross-border mergers and acquisitions. Neutrality of competition is not guaranteed. In the long run, harmonization in the form of a single European supervisory institution 
for all kinds of financial services possibly could become advisable (ECB, 2000a and SCHRÖDER, 2001).

Table 12: Take Over-Directive (turned down by European Parliament on 04.07.01)

\begin{tabular}{|c|c|}
\hline Motivation and objectives & $\begin{array}{l}\text { a minimum level of protection for minority share- } \\
\text { holders of companies subject to take-over bids } \\
\text { which is equivalent throughout the EU; } \\
\text { a basic level of disclosure and information to guar- } \\
\text { antee greater transparency during the take-over bid }\end{array}$ \\
\hline Proponents and their arguments & $\begin{array}{l}\text { British, Danish, French and Swedish MEPs } \\
\text { (Members of European Parliament) generally sup- } \\
\text { ported the directive; } \\
\text { they argued that this directive would have made } \\
\text { the European corporate sector more dynamic and } \\
\text { fairer by requiring shareholders' support before } \\
\text { companies took steps to fight off take-over bids, } \\
\text { thus facilitating hostile take-overs; }\end{array}$ \\
\hline Critics and their arguments & $\begin{array}{l}\text { German MEPs in particular, but also Italian and } \\
\text { - } \\
\text { they argued that there was no effective possibility } \\
\text { for management of the target company to place de- } \\
\text { fensive measures to frustrate a bid without con- } \\
\text { sulting their shareholders; } \\
\text { they further argued that this directive did not se- } \\
\text { cure a level playing field for shareholder rights in } \\
\text { the EU (there are for example 'Golden Shares' } \\
\text { with special rights to vote in some European } \\
\text { countries) from what competitive disadvantages } \\
\text { could arise for some European countries; }\end{array}$ \\
\hline Follow-up & $\begin{array}{l}\text { - according to the European Commission is a new } \\
\text { version of the directive unlikely to ready before } \\
2002 \text {; }\end{array}$ \\
\hline
\end{tabular}

Source: UNION NETWORK INTERNATIONAL (2001)

In addition to these regulative obstacles, different national tax legislation and other legal differences represent market access barriers (QUESTIONING OF LEADING PAN-EUROPEAN BANKING GROUPS, 2001 (Table 9)). For instance, credit collaterals are evaluated differently among European countries, hindering the allocation of cross-border credits. Mergers and acquisitions as the most important strategy of banks examined in this study can be seen as a way to deal with that kind of barrier. In addition, different national accounting standards for companies, bankruptcy principles and take-over arrangements obstruct market access by mergers and acquisition. A common European take-over directive failed in the EU-parliament in 2001 (Table 12). Due to an uncommon take over-legislation as well as missing harmonization of company and taxation legislation, a trend towards cooperations, strategic alliances as well as to joint ventures - like BSCH with Société Générale (F), Royal Bank of Scotland (GB), San PaoloIMI (I) and Commerzbank (D) or BNP Paribas with Dresdner Bank (D) - can be recognized. 
Further harmonization and a stronger institutional coordination of these politically induced market access barriers are useful to accelerate the integration of retail markets in Europe and to achieve further consumer benefits.

\section{Consumer benefits of an integrated European retail market}

The integration of the European retail markets is associated with a number of benefits for consumers. From a macroeconomic point of view, the integration first leads to an accelerated development of financial markets (BUCH, 2000 and LEMMEN, 1998). Through different channels of transmission, the development of financial markets has positive effects on growth in a second step. Important channels in this context are an improved allocation of savings capital as well as the reduction of losses of saving capital. In addition, higher national income and increasing growth also lead to a decreasing rate of unemployment (NEIMKE, EPPENDORFER and BECKMANN, 2002).

Table 13: Price changes for corporate and retail customer deposits since the full implementation of the Single Market Program (1992-1997)

\begin{tabular}{|c|c|c|c|c|c|c|c|c|c|c|c|c|}
\hline Product area & 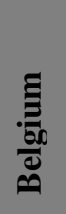 & 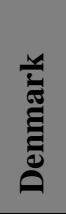 & 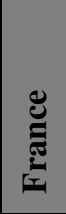 & 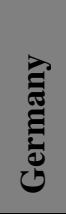 & 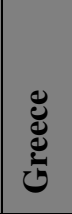 & 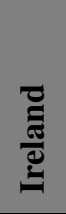 & 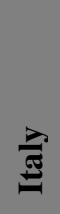 & $\begin{array}{l}\frac{n}{0} \\
\frac{\pi}{\bar{\Xi}} \\
\frac{E}{0} \\
Z\end{array}$ & 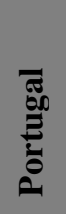 & $\begin{array}{l}\Xi \\
\text { के }\end{array}$ & 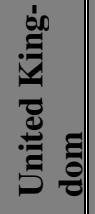 & ?되 \\
\hline $\begin{array}{l}\text { Corporate customer deposits (large } \\
\text { firms) }\end{array}$ & -27 & -18 & -42 & -31 & -28 & -40 & -11 & -22 & -29 & -26 & -21 & -25 \\
\hline $\begin{array}{l}\text { Corporate customer deposits (small } \\
\text { firms) }\end{array}$ & -27 & -13 & -35 & -29 & -30 & -37 & -8 & -30 & -30 & -29 & -19 & -24 \\
\hline Retail customer deposits & -27 & -31 & -35 & -30 & -30 & -37 & -4 & -32 & -25 & -28 & -11 & -23 \\
\hline
\end{tabular}

Price defined as margin between rate paid to customer and money market rate (Changes in margin due to business cycle effects excluded): -50 is 'large decrease', -25 is 'small decrease', 0 is 'no change', 25 is 'small increase', and 50 is 'large increase', Source: EUROPEAN COMMISSION (1997)

From the consumers point of view, increasing integration can be expected to have positive effects on prices, product variety and the quality of services. Stronger competition in the banking sector and lower operating costs conditional on new information and communication technologies goes along with stronger price pressure on financial services. Interests and fees for services decrease, differences between the European countries are reduced. Table 13 provides an overview of price changes for deposits since the implementation of the Single Market Program in 1992. Simultaneously, banks are forced to extend the quality of financial services. Competition in conjunction with technological progress leads to increased financial innova- 
tions and therefore to higher product variety. New technologies also offer consumers more time flexibility, as they do no longer have to rely on branch opening hours to conduct their business (LEYSHON, 2000).

In spite of the limits that are put on the integration of retail markets in the long run, the potential of integration is not exhausted by far. Problems originate from different regulation and taxation that represent barriers to market access for the banking sector and thus for crossborder trade in financial services. Further deregulation and harmonization steps towards a common European financial market are needed to benefit consumers substantially.

\section{Conclusions}

Over the past years, European financial markets have integrated considerably. However, significant differences still persist with regard to different sectors of financial markets. Within the banking sector, the money market as well as the market for wholesale-products already form common European markets. However, there still exists an extensive segmentation of national markets for retail-products. Responsible for this low degree of retail market integration are a line of natural and politically induced barriers to banks` market access. In this paper market access strategies were examined based both on aggregate data for the banking sector and case studies of individual banks (Banco Santander Central Hispano, Nordea Group, BNP Paribas and $H S B C$ ). Four main strategies were considered in particular: direct cross-border sale (telephone- or internet banking), the establishment of branches and subsidiaries, mergers and acquisitions, as well as cooperations and strategic alliances. It can be observed, that in the last years, especially mergers and acquisitions followed by cooperations and strategic alliances strongly contributed to the integration of the European retail markets. Each of the examined strategies, however, still has to deal with considerable barriers to market access. In particular, such barriers are: different national tax legislation, different national consumer protection rules, different national accounting standards and bankruptcy principles, different solvency control, different take-over directives and different national supervision. In order to bypass existing barriers, European banks have to adjust their strategies. For a stronger integration of European retail-markets, further harmonization of legislation and supervision seems to be necessary. A further integration push would especially lead to an increase of consumers benefits through lower prices and higher product variety of financial services. 


\section{References}

ACKeRMAnN, Josef (1998): Intensiver Wettbewerb um Kunden und Kapital, in: Neue Züricher Zeitung, 30.06.1998.

BвC News (2001): Business: The Company File Plan to create Europe's Largest Bank Fails, BBC Online Network, URL: http://bbc.co.uk, $16^{\text {th }}$ October 2001.

BNP PARIBAS (2001). URL: http://www.bnpparibas.com, 01.09.2001.

BSCH (2001): URL: http://bsch.es, October 2001.

BuCH, Claudia (2000): Financial Market Integration in the US: Lessons for Europe?, Kiel Working Paper No. 1004.

Buch, Claudia and Gayle L. DeLong (2001): Cross-Border Bank Mergers: What Lures the Rare Animal, Kiel Working Paper, No. 1070, Kiel, August 2001.

Business\&FinANCE (2001): Enba/BBVA \$1.5bn Banking Merger Collapses, URL: http://businessandfinance.ie, April 2001.

CROWDER, NEIL (1999): Die europäische Bankenlandschaft wird sich verändern, Frankfurter Allgemeine Zeitung, Frankfurt, January 28, 1999.

DATAMONITOR (2000): Retail Banking Frontrunners in Cross-Border Expansion: Banking without Frontiers, New York, London, Frankfurt a.M., Hong Kong, 2000.

DEUTSCHE BANK (2001): URL: http://www.group.deutsche-bank.de, 01.09.2001.

Deutsche Bundesbank (1999): Mögliche Auswirkungen der WWU auf die Bankensysteme der EU auf mittel- bis langfristige Sicht, 1999.

EU (2001a): URL: http://www.europa.eu.int/scadplus/leg/de/s08000.htm, August 2001.

EU (2001b): URL: http://www.europa.eu.int/eur-lex/de/lif/ind/de_analytical_index_06.htm, August 2001.

EUROPÄISCHE KOMMISSION (1999): Finanzdienstleistungen, Umsetzung des Finanzmarktrahmens: Aktionsplan, Mitteilung der Kommission, Luxemburg, 11.05.1999.

EUROPEAN COMMISSION (1997): Credit Institutions and Banking, The Single Market Review, Subseries 2, Vol. 3, Office for Official Publications of the European Communities, Luxembourg 1997.

EUROPEAN COMMISSION (2001): Progress on the Action Plan for Financial Services, URL: http://www.europa.eu.int/comm/internal_market/en/finances/actionplan/annex.pdf, August 2001.

ECB (1999a): , Banking in the euro area: sructural features and trends, in: ECB Monthly Bulletin, Frankfurt a.M., April 1999, S. 41-53. 
ECB (1999b): Possible Effects of EMU on the EU Banking Systems in the Medium to Long Term, Frankfurt a.M., February 1999.

ECB (2000a): EMU and banking supervision, in: ECB Monthly Bulletin, Frankfurt a.M., April 2000, S. 49-64.

ECB (2000b): Mergers and Acquisitions Involving the EU Banking Industry - Facts and Implications, Frankfurt a.M., December 2000.

ECB (2000c): The Euro: Integrating Financial Services, Frankfurt a.M., 2000.

FINANCIAL TIMES DEUTSCHLAND (2001a): Unicredito und Commerzbank brechen Verhandlungen ab, URL: http://www.ftd.de, 11.09.2001.

FINANCIAL TIMES DEUTSCHLAND (2001b): Schwedische Bankenmerger gescheitert, URL: http://www.ftd.de, 20.09.2001.

FORTIS (2001): URL: http://www.fortis.com, 01.09.2001.

Galati, Gabriele And Kostas Tsatsaronis (2001): The Impact of the Euro on Europe's Financial Markets, BIS Working Paper, No. 100, Basel, July 2001.

HABERER, JEAN-Yves (1993): Die künftige Konkurrenz amerikanischer und japanischer Banken nicht ignorieren, in: Handelsblatt, 13.05.1993.

HEINEMANN, FRIEDRICH and JopP, MATHIAS (2002): The Benefits of a Working European Retail Market for Financial Services, Ed.: Institut für Europäische Politik (Berlin), Zentrum für Europäische Wirtschaftsforschung (Mannheim), Bonn.

HSBC (2001): URL: http://hsbc.com, October 2001.

INTESA BCI (2001): URL: http://www.intesabci.it, 01.09.2001.

LEMMEN, JAN (1998): Integrating Financial Markets in the European Union, Cheltenham.

LEYSHON, ANDREW (2000): Financial services mergers and acquisitions: Consumer impacts, University of Nottingham.

NAIRN, GEOFFrey (2000): New Online Opportunities for Banks in the Euro Zone, Financial Times, May 3, 2000.

Neimke, Markus, EpPendorfer, CARsten and Beckmann, Rainer (2002): Deepening European Financial Integration - Theoretical Considerations and Empirical Evaluation of Growth and Employment Benefits, Ruhr-University of Bochum.

NORDEA (2001): URL: http://nordea.com, October 2001.

OECD (2001): Group of Ten, Report on Consolidation in the Financial Sector, January 2001. 
SCHRÖDER, UlRICH (2001): Defizite bei der Verwirklichung der Grundfreiheiten: Auf dem Wege zu einem europäischen Finanzmarkt, Tagung des AEI Bonn mit HWWA Hamburg: Der unvollendete Binnenmarkt, Hamburg, 21. Juni 2001.

SCHÜLER, MARTIN (2002): Integration of the European Market for E-Finance - Evidence from Online Brokerage, Zentrum für Europäische Wirtschaftsforschung (ZEW), Mannheim.

SEB (2001): URL: http.//www.seb.se, 01.09.2001.

THE ECONOMIST (1998): Europe’s Lovesick Bankers, London, January 10, 1998, pp. 59-60.

UNION NETWORK INTERNATIONAL (2001), URL: http://www.union-network.org, 20.07.2001.

WILlmAn, JoHN (2000a): Scope For Further Mergers and Acquisitions, Financial Times, May 26, 2000.

Willman, JoHN ( 2000b): Freeze Or Jump? That is the Question, Financial Times, May 26, 2000. 


\section{Appendix: The major mergers and acquisitions involving European banks since the in- troduction of the Euro}

\begin{tabular}{|c|c|c|c|c|}
\hline \multicolumn{2}{|c|}{ Involved Banks } & \multirow{2}{*}{ Kind of Transaction } & \multirow{2}{*}{\multicolumn{2}{|c|}{$\begin{array}{l}\text { Assets } 31 \text { Dec } 1998 \\
\qquad(B n €)\end{array}$}} \\
\hline Acquirer & Target & & & \\
\hline \multirow{2}{*}{ Deutsche Bank (D) } & \multirow{2}{*}{ Bankers Trust (USA) } & \multirow{2}{*}{ Acquisition } & \begin{tabular}{|l|} 
Deutsche Bank \\
Bankers Trust \\
\end{tabular} & $\begin{array}{l}604 \\
114 \\
\end{array}$ \\
\hline & & & Total & 718 \\
\hline \multirow{2}{*}{$\begin{array}{l}\text { Banque Nationale de Paris } \\
\text { (BNP) (F) }\end{array}$} & \multirow{2}{*}{ Paribas $(\mathrm{F})$} & \multirow{2}{*}{$\begin{array}{l}\text { Merger into } \\
\text { BNP Paribas }\end{array}$} & $\begin{array}{l}\text { BNP } \\
\text { Paribas } \\
\end{array}$ & $\begin{array}{l}325 \\
249 \\
\end{array}$ \\
\hline & & & Total & 574 \\
\hline \multirow{2}{*}{ HSBC Holding Plc (GB) } & \multirow{2}{*}{$\begin{array}{l}\text { Crédit Commercial de } \\
\text { France }(F)\end{array}$} & \multirow{2}{*}{$\begin{array}{l}\text { Integration of CCF into } \\
\text { the HSBC Group }\end{array}$} & \begin{tabular}{|l} 
HSBC \\
Crédit Commercial \\
\end{tabular} & $\begin{array}{r}495 \\
63 \\
\end{array}$ \\
\hline & & & Total & 558 \\
\hline \multirow{2}{*}{ ING Group (NL) } & \multirow{2}{*}{ BHF-Bank (D) } & \multirow{2}{*}{ Acquisition } & $\begin{array}{l}\text { ING Group } \\
\text { BHF-Bank } \\
\end{array}$ & $\begin{array}{r}395 \\
45 \\
\end{array}$ \\
\hline & & & Total & 440 \\
\hline \multirow{2}{*}{$\begin{array}{l}\text { Générale de Banque - } \\
\text { General Bank (B) }\end{array}$} & \multirow{2}{*}{ ASLK/CGER (B) } & \multirow{2}{*}{$\begin{array}{c}\text { Merger } \\
\text { (Today part of the Bel- } \\
\text { gian-Dutch Fortis Group) }\end{array}$} & $\begin{array}{l}\text { Générale de Banque } \\
\text { ASLK/CGER } \\
\end{array}$ & $\begin{array}{r}208 \\
80 \\
\end{array}$ \\
\hline & & & Total & 288 \\
\hline \multirow{2}{*}{ Banca Intesa (I) } & \multirow{2}{*}{$\begin{array}{l}\text { Banca Commerciale } \\
\text { Italiana (BCI) (I) }\end{array}$} & \multirow{2}{*}{ Merger into IntesaBCI } & \begin{tabular}{|l|} 
Banca Intesa \\
BCI \\
\end{tabular} & $\begin{array}{l}153 \\
113 \\
\end{array}$ \\
\hline & & & Total & 266 \\
\hline \multirow{2}{*}{$\begin{array}{l}\text { Banco Santander Central } \\
\text { Hispano (E) }\end{array}$} & \multirow{2}{*}{$\begin{array}{l}\text { Banco Totta \& Açores SA } \\
\text { and Crédito Predial Portu- } \\
\text { gues SA (P) }\end{array}$} & \multirow[t]{2}{*}{ Acquisition } & $\begin{array}{l}\text { BSCH } \\
\text { Totta \& Açores SA } \\
\text { Crédito Predial Portugues SA } \\
\end{array}$ & $\begin{array}{r}234 \\
17 \\
6 \\
\end{array}$ \\
\hline & & & Total & 257 \\
\hline \multirow{2}{*}{ Banco Santander (E) } & \multirow{2}{*}{$\begin{array}{l}\text { Banco Central } \\
\text { Hispanoamericano (E) }\end{array}$} & \multirow{2}{*}{$\begin{array}{l}\text { Merger into Banco } \\
\text { Santander Central } \\
\text { Hispano (BSCH) }\end{array}$} & $\begin{array}{l}\text { Banco Santander } \\
\text { Banco Central Hispanoamericano }\end{array}$ & $\begin{array}{r}154 \\
82 \\
\end{array}$ \\
\hline & & & Total & 236 \\
\hline \multirow{2}{*}{$\begin{array}{l}\text { Crédit Communal de } \\
\text { Belgique (B) }\end{array}$} & \multirow{2}{*}{$\begin{array}{l}\text { Crédit Local de } \\
\text { France }(\mathrm{F})\end{array}$} & \multirow{2}{*}{$\begin{array}{c}\text { Merger } \\
\text { (Today part of the Dexia } \\
\text { Group) }\end{array}$} & $\begin{array}{l}\text { Crédit Communal } \\
\text { Crédit Local } \\
\end{array}$ & $\begin{array}{r}105 \\
99 \\
\end{array}$ \\
\hline & & & Total & 204 \\
\hline \multirow{2}{*}{ Banco Bilbao Vizcaya (E) } & \multirow{2}{*}{ Argentaria (E) } & \multirow{2}{*}{$\begin{array}{c}\text { Merger into Banco Bilbao } \\
\text { Vizcaya Argentaria } \\
\text { (BBVA) }\end{array}$} & $\begin{array}{l}\text { Banco Bilbao Vizcaya } \\
\text { Argentaria } \\
\end{array}$ & $\begin{array}{r}132 \\
70 \\
\end{array}$ \\
\hline & & & Total & 202 \\
\hline \multirow{2}{*}{$\begin{array}{l}\text { Merita Nordbanken Plc } \\
\text { (FI) }\end{array}$} & Unidonmerk $C$ rou $(\mathrm{DK})$ & Merger & \begin{tabular}{|l} 
Merita Nordbanken \\
Unidanmark Group \\
\end{tabular} & $\begin{array}{l}96 \\
70\end{array}$ \\
\hline & D) & to form Nordea & Total & 166 \\
\hline & & $\ldots$ & $\begin{array}{l}\text { SEB } \\
\text { BfG } \\
\end{array}$ & $\begin{array}{l}73 \\
42 \\
\end{array}$ \\
\hline SEB (S) & BfG (D) & Acquisition & Total & 115 \\
\hline
\end{tabular}

Source: Following ECB (2000a), ECB (2000c), DEUTSCHE BANK (2001), BNP PARIBAS (2001), FORTIS (2001), INTESA BCI (2001), BSCH (2001), SEB (2001). 


\section{Diskussionsbeiträge des Instituts für Europäische Wirtschaft}

Nr. 1 Peter M. Schmidhuber: Die Vertiefung des Gemeinsamen Marktes und die Bewältigung der zweiten Stufe der Wirtschafts- und Währungsunion. Bochum 1994.

Nr. 2 Dieter Schneider: Sichert das Standortsicherungsgesetz die Attraktivität Deutschlands als Wirtschaftsstandort für ausländische Unternehmen? - Eine Teilantwort anhand effektiver Grenzsteuerbelastungen für US-Direktinvestitionen in Deutschland. Bochum 1994.

Nr. 3 Wim Kösters: On the Stability Conception of the Maastricht Treaty: Interpretation and Critical Assessment. Bochum 1994.

Nr. 4 Cay Folkers: Die Kompensationsfunktion des Europäischen Haushalts - Zur ökonomischen Analyse der EU-Finanzen im Integrationsprozeß. Bochum 1994.

Nr. 5 Dieter Bender, Norbert Lamar: EWS-Bandbreitenerweiterung, Konvergenz und Währungsunion. Bochum 1995.

Nr. 6 Wim Kösters, Ansgar Belke: The Unemployment Problem in the EU: Theories and Evidence. Bochum 1995.

Nr. 7 Ansgar Belke: Testing for Unit Roots in West German an U.S. Unemployment Rates: Structural Breaks or Stochastic Trends in European Unemployment? Bochum 1996.

Nr. 8 Ansgar Belke: Maastricht - Implikationen einer zentralisierten Geld- und Währungspolitik für die Beschäftigung in Europa. Bochum 1996.

Nr. 9 Ansgar Belke: Wechselkursfixierung in einer EWU: Chance oder Risiko für die Beschäftigung in Westeuropa? Bochum 1996.

Nr. 10 Peter Hammann, Thorsten Stritzki, Cordula Tebbe: Das Key-Account-Management als Reaktion auf die Handelsentwicklung in Europa - eine empirische Untersuchung am Beispiel der Kosmetikindustrie. Bochum 1996.

Nr. 11 Ansgar Belke: Zur Politischen Ökonomie der Westeuropäischen Arbeitslosigkeit: Mancur Olson versus Insider-Outsider-Theorie. Bochum 1996.

Nr. 12 Berthold Busch, Karl Lichtblau, Claus Schnabel: Kohäsionspolitik, Konvergenz und Arbeitslosigkeit in der Europäischen Union: Eine empirische Analyse mit Regionaldaten. Bochum 1997. 
Nr. 13 Ansgar Belke, Daniel Gros: Evidence on the Costs of Intra-European Exchange Rate Variability. Bochum 1997.

Nr. 14 Ingo Pies: Globalisierung und Demokratie: Chancen und Risiken aus ökonomischer Sicht. Bochum 1997.

Nr. 15 Ansgar Belke: Setting Euro Conversion Rates: A Comment on the de Grauwe-Proposals. Bochum 1997.

Nr. 16 Ansgar Belke, Daniel Gros: Estimating the Costs and Benefits of EMU: The Impact of External Shocks on Labour Markets. Bochum 1997.

Nr. 17 Dieter Bender, Norbert Lamar: European Financial Integration and EMU Expectations. Bochum 1997.

Nr. 18 Ansgar Belke: EWU, Geldpolitik und Reform der Europäischen Arbeitsmärkte. Bochum 1997.

Nr. 19 Ansgar Belke, Daniel Gros: Modelling the „Option Value of Waiting“: More Evidence on the Costs of Intra-European Exchange Rate Volatility. Bochum 1998.

Nr. 20 Wim Kösters: Europäische Integration: Wirtschaftspolitischer Autonomieverlust durch Supranationalisierung politischer Entscheidungen. Bochum 1998.

Nr. 21 Ingo Pies: Liberalismus und Normativität: Zur Konzeptualisierung ökonomischer Orientierungsleistungen für demokratische Politikdiskurse. Bochum 1998.

Nr. 22 Ansgar Belke, Matthias Göcke: A Simple Model of Hysteresis in Employment under Exchange Rate Uncertainty. Bochum 1998.

Nr.23 Ansgar Belke, Matthias Göcke: Micro- and Macro-Hysteresis in Employment under Exchange Rate Uncertainty. Bochum 1998.

Nr. 24 Ansgar Belke, Daniel Gros: Asymmetric Shocks and EMU: On a Stability Fund. Bochum 1998.

Nr. 25 Cay Folkers: Neue Maßstäbe in der Europäischen Union: Grenzen für Staatsverschuldung und Staatsquote durch den Maastrichter Vertrag und seine Ergänzungen. Bochum 1999. 
Nr. 26 Un-Chan Chung: East Asian Economic Crisis - What is and What Ought to be Done: The Case of Korea. Bochum 1999.

Nr. 27 Ansgar Belke: Beschäftigungswirkungen institutioneller Arbeitsmarktunterschiede und währungspolitische Arrangements bei stufenweiser EU-Osterweiterung. Bochum 1999.

Nr. 28 Ansgar Belke: Towards a Balanced Policy Mix under EMU: Co-ordination of Macroeconomic Policies and ,Economic Government'? Bochum 1999.

Nr. 29 Gerhard Wegner: Zur Funktionsfähigkeit des institutionellen Wettbewerbs - Ein Beitrag zur Theorie des Systemwettbewerbs. Bochum 2000.

Nr. 30 Ansgar Belke, Daniel Gros: Designing the EU-US Atlantic Monetary Relations: The Impact of Exchange Rate Variability on Labor Markets on Both Sides of the Atlantic. Bochum 2000 .

Nr. 31 Rainer Beckmann, Martin Hebler, Wim Kösters, Markus Neimke: Theoretische Konzepte zum Europäischen Integrationsprozeß: Ein aktueller Überblick. Bochum 2000.

Nr. 32 Ansgar Belke: Lohnpolitik in der EWU - Stabilisierender oder destabilisierender Faktor? Bochum 2000.

Nr. 33 Elena Diaz Porta, Martin Hebler, Wim Kösters: Mercosur: Auf dem Weg zu einer Zollunion. Bochum 2000.

Nr. 34 Sonja Eckey, Markus Neimke: Regionale Integrationsdynamik aus Sicht der Neuen Politischen Ökonomie. Bochum 2000.

Nr. 35 Rainer Beckmann, Carsten Eppendorfer, Markus Neimke: Europäische Finanzmarktintegration und Wirtschaftswachstum. Bochum 2001.

Nr. 36 Jens M. Heine, Wim Kösters: Zur politischen Ökonomik der EWU: Vom Währungswettbewerb zum Monopol. Bochum 2001.

Nr. 37 Ansgar Belke: Too Big to Fail - Bankenkonkurs, ,Bailout' und Wählerstimmenkalkül. Bochum 2001.

Nr. 38 Rainer Beckmann, Jürgen Born, Wim Kösters: The US dollar, the euro, and the yen: An evaluation of their present and future status as international currencies. Bochum 2001. 
Nr. 39 Ansgar Belke, Carsten Eppendorfer und Jens M. Heine: Zur Bedeutung unterschiedlicher Finanzmarktstrukturen für den geldpolitischen Transmissionsprozess in der EWU. Bochum 2001.

Nr. 40 Rainer Beckmann, Carsten Eppendorfer, Markus Neimke: Financial integration within the European Union: Towards a single market for insurance. Bochum 2002.

Nr. 41 Carsten Eppendorfer, Rainer Beckmann, Markus Neimke: Market Access Strategies in the EU Banking Sector: Obstacles and Benefits towards an integrated European Retail Market. Bochum 2002.

Nr. 42 Markus Neimke, Carsten Eppendorfer, Rainer Beckmann: Deepening European Finacial Integration: Theoretical Considerations and Empirical Evaluation of Growth and Employment Benefits. Bochum 2002. 